Науковий вісник Чернівецького університету імені Юрія Федьковича: Історія. - № 1. - 2020.- С. 104-112 History Journal of Yuriy Fedkovych Chernivtsi National University. - № 1. - 2020. - pp. 104-112

DOI https: /doi.org/10.31861/hj2020.51.104-112

hj.chnu.edu.ua

УДК 930:339.1-051(477)«14/18»

\title{
ФЕНОМЕН УКРАЇНСЬКИХ ЧУМАКІВ У ПРАЦЯХ НАУКОВЦІВ
}

Стаття присвячена проблемі дослідження досить традиційного промислу украйнського народу - чумачтва. Воно розглядається як феномен, унікальне господарсько-побутове явище в історії Украӥни. Історія чумацтва охоплюе XV-XIX ст., а вивчати це явище почали детально лише у XIXХХ ст. На основі иих напрацювань доведено оригінальність матеріальної та духовної культури чумацтва. Психологічний тип чумака сформований в умовах украйнського степу й лісостепу, увібрав у себе ментальність українського народу - хлібороба і козака, доповнивщи і купецькими рисами. Чумаки як активна складова українського етносу відіграли помітну роль у творенні начії.

Ключові слова: чумацтво, чумачький промисел, матеріальна культура, духовна культура, чумацький звичай, громада, Украйна.

\section{Liliia Drobina (Chernivtsi)}

\section{UKRAINIAN CHUMAKS PHENOMENON IN THE WORKS OF SCIENTISTS}

Abstract. The article is dedicated to the issues of studying the fairly traditional craft of the Ukrainian people-Chumak business (Chumatstvo). It is considered as a phenomenon, a unique business and household phenomenon in the history of Ukraine. The history of the Chumatstvo covers the 15th-19th centuries. And they began to study this phenomenon in detail only in the 19th-20th centuries. Most part of researchers did not consider Chumatstvo as an independent phenomenon of the historical existence of the Ukrainian people, but exclusively as a continuation of the Cossacks. They were interested in the origin of the word "Chumak», authentic means of transportation of carts, and the Ukrainian breed of gray oxen. Rich material on Chumak customs had been preserved in the works of ethnographic expeditions and artworks of the 19th century, but the most interesting source was Chumak folklore, namely Chumak songs. Based on these developments, the originality of the material and spiritual culture of the Chumatstvo is proved. The psychological type of Chumak was formed in the conditions of the Ukrainian Steppe and Forest-Steppe, it incorporated the mentality of the Ukrainian people - the farmer and the Cossack, supplementing with merchant features. Relations between the Chumaks were based on mutual assistance and mutual aid and provided for the protection of the person and property of comrades. Ukrainian fraternities, which were formed in the cities as part of artisan and merchant guilds, were reflected in the Chumaks caravans. Chumak community turned out to be quite viable, as it was able to survive almost unchanged until the middle of the 19th century. Its decline was caused by economic changes, including the reorientation from independent trade to carriage, the emergence of railways and steamships; social and property stratification of Chumatstvo; changes in social psychology. Chumaks, as an active component of the Ukrainian ethnic group, played a prominent role in the nation creating process.

Keywords: Chumatstvo, Chumak business, material culture, spiritual culture, Chumak customs, community, Ukraine.

* к.і.н., асистент кафедри історії України Чернівецького національного університету імені Юрія Федьковича.

PhD in History, Assistant Professor, the Department of History of Ukraine, Yuriy Fedkovych Chernivtsi National University.

orcid.org/0000-0002-8598-4795

Email: lildrobina@gmail.com 
Сучасні російські політики, як і їх попередники понад сто років тому, намагаються переконати світову громадськість, що українці - це складова російського світу на чолі з Москвою, тому важливими є дослідження української історії та етнографії часів існування Російської імперії. Адже вони дають змогу показати численні культурно-побутові, звичаєві, ментальні та інші відмінності між двома народами, зафіксовані і опрацьовані дослідниками.

Актуальність теми визначається тим, що чумацтво можна назвати унікальним господарськопобутовим явищем в історії України, яке сформувалося на основі традицій соціально-економічного розвитку українського народу. Воно не має аналогів у всесвітній історії, зокрема Н. Букатевич встановив, що чумацтво було автентичним, суто українським промислом і не містило жодних запозичень від інших етносів у виробничих прийомах, соціальній організації, побуті та духовній культурі; хоч і мало зв'язок з козацькою традицією, але було цілком самостійним явищем. Воно істотно вплинуло на формування національної свідомості українців. «Чумакували не тільки звичайні селяни, а й міщани, і «люстрові» (реєстрові) козаки; цього промислу не цурались навіть січовики й дрібна шляхта» ${ }^{1}$.

Мета дослідження полягає в тому, щоб, спираючись на напрацювання попередників щодо дослідження чумацтва, обгрунтувати оригінальність цього соціокультурного явища.

Результати дослідження. Інтерес до українського чумацтва виник у другій половині XIX ст. Фольклорно-етнографічна тематика зацікавила істориків, етнографів, фольклористів, і вже перші праці вказували на автентичність та унікальність цього явища української історії.

Щоб сформувати свою думку щодо чумаків, варто звернутися до походження терміна, яке тлумачиться по-різному. Досить поширеною $є$ версія, в якій слово «чумак» пов'язують із словом «чума» ${ }^{2}$, яку чумаки начебто завозили з Криму, через що вони носили і чумну дігтяреву сорочку. Проте дослідник Г. Данилевський стверджував, що «чумна сорочка, це була одна із двох сорочок, яку чумак брав із собою в дорогу, і яку для захисту від дощу, пилу, різної зарази і мошки відразу ж вимазував дьогтем» ${ }^{3}$.

Більшість дослідників звертаються до тюркського походження слова. Г. Максимович пов'язував це із вживанням слова «чум» або «чюм», що означало «ківш» 4 . Г. Данилевський наголошував, що воно означає «перевізник»5. Ще одна гіпотеза називає слово «пірнальник». 3 цього приводу сучасний науковець, сходознавець і тюрколог Г. Халимоненко стверджує, що «серед науковців тюркського світу дослідження даного слова не здійснювалось, тому що для тюрків воно було чуже, десь за межами їхнього світу» ${ }^{6}$. Це й справді так, чумацтво - явище, можна сказати, винятково українське, як і козаччина. Ці етнічно-соціальні рухи зароджувалися в тюркському суспільстві, де швидко й згасали, і лише в Україні на міцному економічному й політичному підгрунті набрали сили. Тому походження цих слів має в собі, як вважає науковець, тюркське походження, відзначаючи такий ланцюжок подій. Важливою ланкою процесу добування солі та вилову риби є занурювання та пірнання у море чи річку. Очевидно, діяла певна корпорація людей, які добували сіль, ловили рибу, серед них могли бути й українці, наприклад, з колишніх невільників чи так звані туми - «особи, в котрих один $з$ батьків турок чи татарин, а другий українець»'. У зв'язку з цим і з'являється слово «тумак» - християнин, що народився у Криму. Можливо, саме оті туми, працюючи на соляних промислах, ставали при нагоді постачальниками солі й тараньки, але найважливіше те, що вони виступали сполучною ланкою у взаєминах з мусульманським населенням Криму, коли йшлося про безпеку пересування. Врешті гіпотеза формування чумацьких ватаг 3 цього двомовного контингенту також має право на існування. Адже і в українській, і тюркській мовах, як вказує дослідник, слово «тумак» означає «метис, нечистокровний», зустрічається і визначення «дитина раба». Отже, на територіях, підвладних Кримському ханату, т. зв. туми/тумаки, очевидно, мали тісні контакти з чумаками, і в певному середовищі термін «чумак» міг сприйматися вже не тільки зі своїм прямим значенням «людина, що пов’язана з процесом видобутку солі», а й «особа-метис, що поєднана з корпорацією українців, які довозять з Криму сіль, рибу тощо» ${ }^{8}$. Можливо, саме в таких умовах формувалась і поведінка чумаків, де була відсутня зверхність стосовно кого б то не було. Стереотипна упередженість українців стосовно татар, поляків та євреїв не була притаманною чумакам. Натомість характерними були шанобливе ставлення до представників інших націй, толерантність щодо віросповідань та звичаїв інших народів 9

3 наведених вище варіантів пояснення походження назви «чумак» прижилося поняття «візник і 
торговець, який перевозив на волах хліб, сіль, рибу та інші товари для продажу» ${ }^{10}$. Згодом утворився тип людини-чумака з його особливими звичками, побутовими рисами і професійними навичками. Звичайно, для утворення такого типу перевізника були потрібні не роки, а століття. Чумаки - це категорія населення України, що в XV-XIX ст. займалося торговельно-візницьким промислом. Від назви цієї групи населення бере назву і весь промисел - чумацтво.

Чумаки як значна складова українського етносу відіграли вагому роль у націотворчому процесі. I, розглядаючи автентичність українських чумаків, можна виділити два напрямки: духовна і матеріальна культура.

Основу матеріальної культури чумацтва становили засоби пересування. Це було зумовлено самим характером промислу, який передбачав переміщення значних вантажів на великі відстані. У чумацькому промислі головним транспортом були важкі вози-мажі, як їх називали самі чумаки, та воли сірої української породи з великими рогами. Мажа - це чумацький віз, призначений для перевезення вантажів на великі відстані. Їх робили в основному самі чумаки ${ }^{11}$. Французький військовий інженер Ле-Пле, оглянувши чумацького воза, сказав: «Волові вози в своїй будові поєднували величезну простоту з чумацькою дотепністю» ${ }^{12}$.

Етнограф П. Рябков вивченню цього феномену української культури приділив значну увагу. Етнографічне дослідження матеріальної культури чумаків під назвою «Чумацький віз» (1910р.) містить єдині в своєму роді креслення чумацького воза (мажі) з точними обмірами і назвами кожної 3 деталей ${ }^{13}$. У рукописі П. Рябков детально описав південний варіант чумацького воза ${ }^{14}$. Чумацький віз (мажа) складався зі снасті, ящика, війя, чотирьох коліс та ярма. За вантажопідйомністю (за місткістю солі) мажі поділялися на малі, середні та великі. На найбільші навантажували до 120 пудів, на найменші - до 60. Сам віз важив від 22 до 30 пудів ${ }^{15}$.

Чумацькі засоби пересування й тяглова сила (вози й воли) мали виключно автентичне походження. Адже чумацькі вози виготовлялися з одних і тих же сортів деревини, майже без використання металу (для скріплювання частин використовувалися дерев'яні або шкіряні деталі). Як вказує С. Проскурова: «В етимології термінів, що стосувалися будови чумацького воза, практично відсутні західноєвропейські та тюркські впливи, і лише металеві деталі воза мають назви, що походять 3 німецької» ${ }^{16}$.

Крім воза-мажі, не менш унікальними є українські воли як тяглова сила. Воли - це перша турбота чумака, адже без них чумацтво на мало ніякого сенсу, оскільки саме за допомогою виключно їх тяглової сили відбувалося перевезення товарів чумаками. Ніщо не могло зрівнятися з витривалістю саме чумацьких волів. До них були сформовані і певні вимоги. Історик В. Щербатюк виділяє таке: «Воли повинні були бути сірими, довжина ріг мала бути щонайменше півтора аршини в сторони. Чумацький віл повинен був іти рівно, не шкутильгати і не бити п'яткою. Назви волам давали переважно такі: Дунай, Журавель, Чорноморець, Юзко, Юрко, Сикса, Розвага, Буг, Ріжко, Кевондзь, Козак, Лебідь, Сокіл та ін. Щоб воли були кучерявими, їх мили водою і витирали соломою. Хвости розчісували дерев'яною гребінкою, роги чистили склом і витирали кожушкою так, щоб ті блищали. Налигачі для волів були ремінні, інколи - шовкові. Деяким волам чумаки, будучи в Одесі, інколи золотили роги. Влітку волів пасли, взимку кормили і напували тричі на день» ${ }^{17}$.

Ось і все, що стосується матеріальної культури чумаків, адже вони своє життя проживали або в дорозі, або вдома, де підлаштовувались під звичні умови проживання.

А от духовна культура чумаків була культурою окремої групи, і досить багатою. Про це свідчить наявність певних відмінностей чумацьких ритуалів, обрядів та звичаїв від загальноукраїнських, розгалужена ритуалізація повсякденного життя чумаків. Порівнюючи тексти чумацьких пісень, можна простежити такі напрямки - селянський, козацький та купецький. Саме вони є складовими психологічного портрета чумака ${ }^{18}$.

На виникнення чумацтва, на думку О. Кульчицького, поряд з історичними та соціально-економічними факторами вплинули також географічні ${ }^{19}$. Помірний і теплий клімат лісостепу сприяв формуванню життєрадісності й оптимізму, а степовий клімат наклав свій відбиток у непостійності і різкості, контрастності почуттів ${ }^{20}$. Емоційно-почуттєві чинники знайшли своє вираження в пісенній творчості. Наявність в українському пісенному фольклорі циклів козацьких і чумацьких пісень $\epsilon$ унікальним явищем. Збереглися записані етнографами від самих чумаків та їхніх нащадків захо- 
плюючі враження про той спів: «Ніхто так гарно не вмів співать, як чумаки. То ж, було, як заспівають, так усі ліси, яри, гори і поля заговорять. Вони й любили співать і співали, де були... Як їдуть, було, то аби тілько на віз сів, та й співає. Вони не могли на возі тихо сидіти, хіба тілько тоді, коли хліб святий їсть, мусив мовчати, а як наївсь, знов співає» ${ }^{21}$. Цей феномен добре пояснив великий знавець українського мелосу Олександр Кошиць у своїх лекціях, прочитаних у Колумбійському університеті, відзначаючи: «...степові простори, безкрає небо й тиша, самостійність і поезія далекої мандрівки хвилювали творчий дух і він виливався у пісні, повні степової меланхолії й краси, яка $є$ найкращим зразком української поезії і музики» 22.

Аналіз фольклорних пам'яток, зокрема чумацьких пісень зі збірок I. Рудченка 23 , П. Чубинсько$\Gamma^{24}$, С. Тобілевича ${ }^{25}$, дозволив визначити основні риси духовної культури чумаків, їхньої психології.

Якщо говорити про зовнішній вигляд, то першим на це звернув увагу дослідник чумацького промислу в Україні польський історик Зенон Леонард Фіш (псевдонім - Тадеуш Падаліця). У 1841 p. він опублікував працю «Чумаки», в якій розглядав чумаків як окрему категорію («Klasa») людей, відмінних за фізичними даними і психічним складом від іншого населення України, особливу увагу звертав на фізичні особливості і підготовку чумаків ${ }^{26}$. Адже чумак був здатен протягом тривалого часу переносити значні фізичні й психологічні навантаження, протистояти небезпекам, що підстерігали під час пересування степовими шляхами.

Українські письменники Г. Квітка-Основ'яненко, Марко Вовчок, П. Куліш, І. Новицький у своїй творчості також часто використовували чумацьку тематику. Проте найбільш відомі твори - Т. Шевченка ${ }^{27}$ : «Катерина», «Гайдамаки», «Наймичка», «Неначе степом чумаки», малюнки «Андруші», «Коло Седнева» i «Чумаки серед могил», де зображене життя чумаків.

У творах Т. Шевченка чумак обов'язково носив на голові смушеву шапку, не бриль, як зображували пізніше. «Це був би великий сором для всього чумацтва, якби хто з чумаків наклав на голову бриля. То тільки оті легкі ходять у брилях, що з косою за вітром бігають, а чумакові у брилі непристойно, чумак мусить бути тільки в шапці й тоді його можна вважати за чумака», - так пояснювали нащадки чумаків Софії Терещенко. Шапки скидали лише перед Богом: «Я бачу, як ідуть валки попід село, як чумаки йдуть без шапок і Богу моляться» ${ }^{28}$. Дослідник В. Яременко виділив ідею про унікальність українського чумацтва, вказавши, що «українські шапки» є не лише етнографічним атрибутом, який використано при зображенні козацтва, чумацтва, парубоцтва, а й має глибокий символічний зміст, вказує на ознаку лицарської гідності та волелюбності української людини ${ }^{29}$.

Не менш цікавим $є$ вказування Лідії Орел, що рушник чи хустка з квітами, птахами, вишиті матір'ю, дружиною чи коханою були для подорожніх, зокрема і чумаків, «щемним спомином про рідну домівку» і до них ставилися по-особливому ${ }^{30}$. Образ вірної дівчини, яка вишивала молодому чумакові хустину та у «віконце поглядала, чи не ревуть круторогі, чи не йде чумак 3 дороги», простежується в художньо-етнографічних працях. Так, у розвідці Г. Данилевського «Побут і звичаї українських чумаків» повідомляється: «Дівчина на прощання, за звичаєм, дає в руки своєму нареченому, з ким вона вже давно «женихається», вишивану хустку. Він ії береже, як заповіт, усю дорогу, і якщо помирає в дорозі, товариші накривають йому в могилі нею обличчя, бо коли вже яка дівчина в такий час подарує чумакові хустку, то це все одно, що вона з ним заручилася й ні за кого не вийде заміж. А коли чумак помирає в дорозі, на місці поховання ставлять тичку із хусткою» ${ }^{31}$.

На формування українського чумацтва вплинула і постійна інтервенція, яку український народ протягом XV-XVIII ст. відчув не тільки стосовно своїх земель, а й у торговельній справі, де головними учасниками були крамарі-міщани. Перетворення українських міст спочатку в польські (часи Речі Посполитої), а потім російські (Російська імперія) призвело до того, що торгівля потрапила в руки іноземців (поляків, росіян і євреїв). Але захопивши торгівлю і промисли в містах, вони відтиснули українських крамарів, але довго не могли справитися з іншим видом торгового промислу - чумацтвом, яке збереглось майже в первозданному вигляді до XIX ст. На думку I. Рудченка, «чумацтво - одна 3 найцікавіших економічних рис українського народу, яке виробило торгове заняття відповідно певних ідеалів» ${ }^{32}$. Чумаки - виключно народні торговці - відігравали значну роль у зовнішній торгівлі. Про чумаків ми знаємо як про торговців сіллю. А чи були вони такими постійно, як сформувалася така група, що вплинуло на їх становлення?

Чумацьку корпоративну громаду було побудовано на принципах напіввійськової організації 
купецьких караванів доби раннього середньовіччя. Вони утримували наймані озброєні загони для захисту своїх караванів у чужих землях. Так само і чумацькі валки XVI-XVIII ст. являли собою озброєні та належним чином організовані загони, готові в будь-який час до захисту свого майна та життя від численних нападників.

Варто відзначити, що більшість учених розглядали чумацтво не як самостійне явище історичного буття українського народу, а виключно крізь призму козацтва, як його продовження. Відомий історик М. Костомаров появу чумацтва пов'язує з часом занепаду козаччини. Як аргумент наводить військову організацію чумацьких валок: мовляв, колишні козаки стали чумаками та хліборобами ${ }^{33}$.

Даючи свою оцінку, історик Д. Яворницький писав, що «у всіх торговельних стосунках запорозьких козаків із сусідами й сусідів ... із запорожцями першу і незмінну роль грали так звані чумаки». Історик вважав чумацтво «зародком національного українського купецтва, заснованого на засадах суто товариської асоціації», що «воно зародилося набагато раніше за появу на дніпровському Низу козацтва і навіть послужило прототипом самого козацтва, адже перші чумаки були і торговцями, й промисловцями й водночас воїнами» ${ }^{34}$. Саме риси селянина, воїна і торговця сприяли формуванню феномену чумацтва, зазнавши значного впливу з боку як козацької, так і цехової організацій.

Чумацька валка була об’єднанням рівноправних господарів. Її організація базувалася на особистій відповідальності кожного за успіх спільної справи. Управління повсякденним життям валки здійснював отаман, якого обирали загальним голосуванням із суворим дотриманням стародавніх ритуалів. Отаман мав значні повноваження. В козацький період на нього перш за все покладалися обов'язки військового ватажка; пізніше він став адміністратором, який мав забезпечувати належний порядок під час подорожі та гарантувати надійний прибуток для кожного чумака.

Що стосується взаємовідносин чумаків із запорожцями, то економічна політика Війська Низового Запорізького полягала у створенні сприятливих умов для торгівлі, зокрема чумацької. Запорізька старшина під час пересування чумаків землями «військового скарбу» брала плату за військовий супровід і захист чумаків. У результаті, коли чумаки самостійно змушені були пересуватись вже землями Кримського ханства, для захисту своїх валок використовували козацький «табір» із возів.

Відносини між чумаками грунтувалися на взаємодопомозі та взаємовиручці й передбачали оберігання особи та майна товаришів. Українські братства, які утворювались в містах як частина ремісничих і купецьких гільдій, знайшли своє відображення і в чумацьких валках. Проявами купецького цеху, на думку С. Проскурової, були відносна незалежність, перш за все економічна, сувора регламентація повсякденного життя як у дорозі, так і вдома (спільна каса, право товариства на втручання в приватні економічні інтереси ватажан, спільні свята, кругова порука, опікування вдовами й сиротами $)^{35}$. Як і міські цеховики, і козаки, чумаки брали активну участь у житті церковних громад, мали й небесного покровителя - Матір Божу Одигітрію.

Міські ремісничо-купецькі цехи з чітким поділом на учнів, підмайстрів та майстрів, писаним статутом, розвиненим самоуправлінням не знайшли чіткого становлення в чумацькій валці. Адже до неї практично на рівних правах входили наймити і навіть мали право голосу під час виборів отамана.

Чумацька громада виявилась досить життєздатною, адже змогла проіснувати практично без змін до середини XIX ст. До їі занепаду призвели економічні трансформації, серед яких переорієнтація з самостійного ведення торгівлі на візництво, поява залізниць і пароплавів; соціально-майнове розшарування чумацтва; зміни в суспільній психології. «Починаючи з другої половини XIX ст., - відзначає С. Проскурова, - валку традиційного «запорізького» типу (з виборним отаманом і самостійними ватажанами-господарями) витіснили валки «хазяйська» (на чолі з хазяїном) та «наймитська» (на чолі з отаманом-артільником, який був довіреною особою купця-наймача)» ${ }^{36}$.

Корпоративна психологія чумаків була близькою і зрозумілою для більшості українського населення. Тому їхні взаємини з сільськими громадами базувалися на взаємоповазі та взаємодопомозі. Широко відомою була благодійність чумаків стосовно вдів і сиріт. Крім того, чумаки займались не лише торгівлею, а й кредитуванням своїх односельчан як готівкою, так і сіллю та рибою до нового врожаю. Чумаки були своєрідними кредитними установами, адже де в селі взяти кошти на будівництво хати, весілля сина чи дочки, - тому звертались до чумака, який і допомагав при потребі. ${ }^{37}$ Чумакам була притаманна надзвичайна професійна чесність, що робило практично непотрібним укладання з ними офіційних угод. 
Взаємини між ватажанами всередині чумацької корпоративної громади регулювалися виключно «чумацьким звичаєм», що був уособленням психологічного типу чумака і являв собою систему норм звичаєвого та писаного права (Литовські статути). При врегулюванні конфліктних ситуацій вирішальне слово належало отаману. Його влада була значною і простягалася аж до застосування фізичних покарань стосовно правопорушників. Однак такі повноваження він мав лише в дорозі.

Поряд із шанобливим ставленням до власного отамана і старших у чумаків простежується відсутність пієтету перед іншими можновладцями. Кожен чумак був господарем, хазяїном, сповненим гідності й статечності: «Всі чумаки - джигуни й молодці. Заломивши набакир темно-сіру шапку, у білій або чорній свиті до землі наопашки ходить чумак по ярмарку з люлькою в зубах і батогом у руці. ... Почоломкається-поздоровкається з товаришем, постоїть перед загородкою волів, яких вивели на торг, та, глянувши на свої змащені дьогтем чоботи, сплюне набік і знову смокче цибук. ... Дух общини й властолюбства сповнює їх ${ }^{38}$.

За вибором громади будь-який чумак, який мав необхідні для цього особисті якості, міг стати отаманом валки. Тому, як відзначає С. Проскурова, «гідність та владність, неквапливість і небагатослів'я культивував у собі кожен, адже в українському суспільстві на першому місці була не сила, а саме шана» ${ }^{39}$.

«Чумацький звичай» був звабливим для значної частини українського населення. Він обумовлював мотивацію участі пересічного українця в чумацькому промислі. Хоча й відбулося виокремлення чумаків із сільської громади, та характер чумацького промислу сприяв колективному спілкуванню. Саме сидячи біля нічного багаття, отамани і старші чумаки в ході неквапливих бесід передавали молодшим «чумацький звичай» - секрети ремесла, ритуалів, обрядів, звичаїв, фольклору, все те, що складало життєвий, виробничий і соціальний простір чумака.

Чумацький промисел поєднував розмаїту кількість характерних ритуалів, обрядів та звичаїв. Запорізька Січ, чумацькі громади, ремісничі та купецькі цехи середньовічних українських міст були чоловічими громадами. В повсякденному житті січового товариства, чумацької валки, ремісничого цеху зустрічався цілий ряд ритуалів. У запорожців це були ритуали ініціації, виборів отамана, спільної трапези, привітання, поховання загиблих; у чумаків - виборів отамана, прощання з близькими перед мандрівкою, поховання померлих у дорозі, спільних трапез із сільською громадою; у ремісників - ініціації, бенкетів - «братчин», осіннього переходу до роботи при свічках, учнівських мандрів тощо ${ }^{40}$.

Чумацтво було врятоване і розвинуте козацтвом, а пізніше, коли втратило свою славу козацтво, то воно знайшло прихисток серед чумацтва як притулок згаслого рицарства. Адже саме чумаки продовжували ходити старими татарськими і козацькими шляхами. Дух козацтва і як чумацький промисел передавався від діда-прадіда, став спадковим заняттям, увійшов до народного звичаю українців. Чумак у цьому контексті - символ українця, який зберіг християнські чесноти та природний інтерес до минувшини, але його історична та етнічна свідомість зазнала небажаних змін.

Висновки. Протягом чотирьох століть чумацький промисел належав до найважливіших, після землеробства і скотарства, занять сільського населення. Чумацтво широко відбивалось у фольклоpi, де склався цикл так званих чумацьких пісень, у творчості найважливіших українських діячів культури. Фольклор, численні документальні свідчення про чумаків підтверджують їх єдність 3 народом і пошану до їх промислу з боку народу. «Чумаки були дуже справедливі, жили по правді», - так говорили про них сучасники. Були вони, як оповідають в народі, чесними, вільнолюбивими i розсудливими.

Iз припиненням існування чумацтва зник і цілий пласт своєрідної української культури. Щоб зберегти пам'ять про чумацтво, необхідно поглибити дослідження цього унікального явища не лише в українській, але і в європейській історії. Чумацтво протягом кількох сторіч відігравало значну роль у націотворчих процесах, сприяючи створенню національного ринку на українських землях, встановленню взаємовигідних зв'язків із зарубіжжям, підтриманню та збереженню духовних традицій українців.

У результаті вивчення феномену українського чумацтва можна відзначити, що воно виникло на суто українському економічному, соціальному, культурному та психологічному підгрунті. Формування українського етносу протягом тривалого історичного періоду сприяло виникненню чумацтва 
й козацтва. І навпаки, їхні риси можемо простежити і сьогодні у фольклорі, літературі, музиці, живописі, а взагалі - у «колективному підсвідомому» української нації.

1 Цит. за: С. Проскурова, Видатний дослідник чумацтвва 20-30-х років XX cm. [An Outstanding Researcher of the Chumak Business of the 1920s - 1930s.], in: Народна творчість та етнографія, 2000, № 1, с.98.

2 А. Скальковський, История Новой Сечи или последнего кошевого Запорожского [The History of the New Sich or the last Zaporizhzhia Koshovyi], Одесса, 1885, с.105.

3 Г. Данилевський, Чумаки Художньо-документальний нарис. [Chumaks. Fiction and documentary essay], Київ, Веселка, 1992, с.14.

4 Г. Максимович, Українські народні пісні [Ukrainian Folk Songs], Київ, 1834, c.131.

5 Г. Данилевський, Чумаки Художньо-документальний нарис. [Chumaks. Fiction and documentary essay], c.13.

6 Г. Халимоненко, Походження слова чумак [Origins of the "Chumak”], in: «Українська мова», Вип.4, 2010, c. 88 .

7 Г. Халимоненко, Тюркізми у професійно-виробничій лексиці украӥнської мови [Turcisms in the Professional Production Vocabulary of the Ukrainian Language], Київ, 1995, с.23.

8 Г. Халимоненко, Походження слова чумак [Origins of the "Chumak”], c.87.

9 С. Проскурова, Чумаки як виразні носії ментальності та етнічного архетипу украӥния [Chumaks as Expressive Carriers of Mentality and Ethnic Archetype of the Ukrainian], in: Етнічна історія народів Свропи, 2000, №5, c.98.

10 Т. Печериця, Чумацтвво в праияя П.Рябкова (1848-1926 [Chumak Business in Works by P.Riabkov (1848-1926)], in: «Південна Україна XVIII-XIX ст. Записки науково-дослідної лабораторії історії Південної України. Запорізький державний університет». Вип. 7, Запоріжжя, 2002, с.272.

11 В. Кукса, В. Кукса, Чумацькими шляхами Украӥни [Chumak Roads of Ukraine], Київ, Вид-во Політехніка, 2009, с.12.

12 Цит. за: Н Буткевич, Чумачтво на Украйні [Chumak Business in Ukraine], Одеса, 1928, с.67.

13 Т. Печериця, Чумацтво в праиях П.Рябкова (1848-1926 [Chumak Business in Works by P.Riabkov (1848-1926)], c. 274.

14 О. Трибуцька, Матеріали особового фонду Павла Рябкова (до 165-річчя від дня народження відомого вченого-етнографа і громадського діяча) [Materials of Pavel Ryabkov's Personal Fund (on 165th Anniversary of the Birth of Famous Ethnographer and Public Figure)], in: «Історія України: наук.-допом. бібліогр. покажч. за 2013 р.», Київ, 2015, с.139.

15 Т. Печериця, Чумацтвво в прачях П.Рябкова (1848 - 1926 [Chumak Business in Works by P.Riabkov (1848-1926)], с.273.

16 С. Проскурова, Чумацтво як украӥнське соиіокультурне явище:: атореф. дис. ... канд. істор. наук: 09.00.12 [Chumak Business as Ukrainian Social and Cultural Phenomenon: extended abstract of Cand. Sci. (History) Dissertation: 09.00.12], Київ, 2001, с.11.

17 В. Щербатюк, Чумацтвво: торгово-візницький промисел українців [Chumak Business: the trade and business thought of Ukrainians], in: «День». 1999. 16 лип.

18 С. Проскурова, Чумацтво як украӥнське соиіокультурне явище: атореф. дис. ... канд. істор. наук: 09.00.12 [Chumak Business as Ukrainian Social and Cultural Phenomenon: extended abstract of Cand. Sci. (History) Dissertation: 09.00.12], Київ, 2001, с.12.

19 О.Кульчицький, Украӥнський персоналізм: філософська й етнопсихологічна синтеза [Ukrainian Personalism: Philosophical and Ethnopsychological Synthesis], Мюнхен-Париж, 1985, 94 с.

20 С. Проскурова, Чумаки як виразні носії ментальності та етнічного архетипу україния [Chumaks as Expressive Carriers of Mentality and Ethnic Archetype of the Ukrainian], c.94.

21 Чумаки й пісня [Chumaks and Songs], available at: https://ua.raskazka.net/tag/legendi/page/33/

22 О. Кошиць, Про украӥнську пісню і музику [On Ukrainian Song and Music], Київ, Музична Україна, 1993, c.22.

23 И. Рудченко, Чумацкие народные песни [Chumak Folk Songs], Київ, Тип. М.П.Фрица, 1874, с.11, available at: https://elib.nlu.org.ua/view.html?\&id=937

24 Труды этнографическо-статистической экспедиџии в Западно-Русский край, снаряженной Императорским Русским Географическим обществом. Юго-Западное отделение. (Материаль и исследования, собранныле действительным членом П.П.Чубинским) [Proceedings of the Ethnographic-Statistical Expedition to the Western Russian Territory, Equipped with the Imperial Russian Geographical Society. Southwest Branch. (Materials 
and Studies Collected by Full Member P.P. Chubynskyi)]: B 7 т., 1872-1878.

25 Українські народні пісні в записах Софії Тобілевич [Ukrainian Folk Songs in Records of Sofia Tobilevych], Київ, Наук. думка, 1982, 121 с.

26 T. Crumacy, in: Tygodnik Petersburski, 1840, ч. XXI, № 35, c. 180-182.

27 Т. Шевченко, Кобзар [Kobzar], Київ, 1987, 639 с.

28 Українські народні пісні в записах Софї Тобілевич [Ukrainian Folk Songs in Records of Sofia Tobilevych], c.53.

29 В. Яременко, Тарас Шевченко про чумацтво, його звичаї та пісні [Taras Shevchenko on Chumak Business, Its Customs and Songs], in: Народна творчість та етнографія, 2005, №2 (295) березень-квітень, с.21.

30 Л. Орел, Українські рушники (історико-культурологічне дослідження) [Ukrainian Towels (Historical and Cultural Research)], Львів, Кальварія, 2003, с.46.

31 Г. Данилевський, Чумаки Художньо-документальний нарис. [Chumaks. Fiction and documentary essay], c.64-65.

32 И Рудченко, Чумаџкие народные песни [Chumak Folk Songs], c.15, available at: https://elib.nlu.org.ua/ view.html?\&id=937

33 Н. Костомаров, Об историческом значении русской народной поэзии [On Historical Significance of Russian Folk Poetry], in: «Слов'янська міфологія: Вибрані праці з фольклористики й літературознавства», Київ, Либідь, 1994, с.149-150.

34 Д. Яворницький, Історія запорозьких козаків: У 3 m. [History of Zaporizhzhia Cossacks: In 3 vol.], т. 1, Львів, Світ, 1990, с.297-298.

35 С. Проскурова, Чумаки як виразні носії ментальності та етнічного архетипу украӥния [Chumaks as Expressive Carriers of Mentality and Ethnic Archetype of the Ukrainian], in: Етнічна історія народів Свропи, 2000, №5, c.94-99.

36 С. Проскурова, Чумацтво як украӥнське соиіокультурне явище: атореф. дис. ... канд. істор. наук: 09.00.12 [Chumak Business as Ukrainian Social and Cultural Phenomenon: extended abstract of Cand. Sci. (History) Dissertation: 09.00.12], Київ, 2001, с.12.

37 И. Рудченко, Чумаџкие народнье песни [Chumak Folk Songs], c.11, available at: https://elib.nlu.org.ua/ view.html?\&id=937

38 Г. Данилевський, Чумаки Художньо-документальний нарис. [Chumaks. Fiction and documentary essay], c.53-54.

39 С. Проскурова, Чумаки як виразні носії ментальності та етнічного архетипу украӥнияя [Chumaks as Expressive Carriers of Mentality and Ethnic Archetype of the Ukrainian], c.98.

40 С. Проскурова, Чумаки як виразні носії ментальності та етнічного архетипу украӥния [Chumaks as Expressive Carriers of Mentality and Ethnic Archetype of the Ukrainian], c.96.

\section{References}

1. N. Butkevych, Chumatstvo na Ukraini [Chumak Business in Ukraine], Odesa, 1928, 240 s.

2. H. Danylevskyi, Chumaky Khudozhno-dokumentalnyi narys. [Chumaks. Fiction and documentary essay], Kyiv, Veselka, 1992, $110 \mathrm{~s}$.

3. T.Crumacy, in: Tygodnik Petersburski, 1840, ч. XXI, № 35, c. 180-182.

4. N. Kostomarov, Ob ystorycheskom znachenyy russkoi narodnoi poэzyy [On Historical Significance of Russian Folk Poetry], in: «Slovianska mifolohiia: Vybrani pratsi z folklorystyky y literaturoznavstva», Kyiv, Lybid, 1994, s.44-49.

5. O. Koshyts, Pro ukrainsku pisniu i muzyku [On Ukrainian Song and Music], Kyiv, Muzychna Ukraina, 1993, $50 \mathrm{~s}$.

6. V. Kuksa, V. Kuksa, Chumatskymy shliakhamy Ukrainy [Chumak Roads of Ukraine], Kyiv, Vyd-vo Politekhnika, 2009, s. 9-20.

7. O.Kulchytskyi, Ukrainskyi personalizm: filosofska y etnopsykholohichna synteza [Ukrainian Personalism: Philosophical and Ethnopsychological Synthesis], Miunkhen-Paryzh, 1985, 194 s.

H. Maksymovych, Ukrainski narodni pisni [Ukrainian Folk Songs], Kyiv, 1834, 180 s., URL: http://irbis-nbuv. gov.ua/cgi-bin/ua/elib.exe

8. L. Orel, Ukrainski rushnyky (istoryko-kulturolohichne doslidzhennia) [Ukrainian Towels (Historical and Cultural Research)], Lviv, Kalvariia, 2003, 232 s.

9. T. Pecherytsia, Chumatstvo v pratsiakh P.Riabkova (1848-1926 [Chumak Business in Works by P.Riabkov (1848-1926)], in: «Pivdenna Ukraina KhVIII-KhIKh st. Zapysky naukovo-doslidnoi laboratorii istorii Pivdennoi Ukrainy. Zaporizkyi derzhavnyi universytet». Vyp. 7, Zaporizhzhia, 2002, s.272-276. 
10. S. Proskurova, Chumatstvo yak ukrainske sotsiokulturne yavyshche: atoref. dys. ... kand. istor. nauk: 09.00.12 [Chumak Business as Ukrainian Social and Cultural Phenomenon: extended abstract of Cand. Sci. (History) Dissertation: 09.00.12], Kyiv, 2001, 19 s.

11. S. Proskurova, Chumaky yak vyrazni nosii mentalnosti ta etnichnoho arkhetypu ukraintsia [Chumaks as Expressive Carriers of Mentality and Ethnic Archetype of the Ukrainian], in: Etnichna istoriia narodiv Yevropy, 2000, №5, s.94-99.

12. S. Proskurova, Vydatnyi doslidnyk chumatstva 20-30-kh rokiv KhKh st. [An Outstanding Researcher of the Chumak Business of the 1920s - 1930s.], in: Narodna tvorchist ta etnohrafiia, 2000, № 1, s. 98-104.

Y. Rudchenko, Chumatskye narodnыe pesny [Chumak Folk Songs], Kyiv, Typ. M.P.Frytsa, 1874, 240 s., URL: https://elib.nlu.org.ua/view.html?\&id=937

13. A. Skalkovskyi, Ystoryia Novoi Sechy yly posledneho koshevoho Zaporozhskoho [The History of the New Sich or the last Zaporizhzhia Koshovyi], Odessa, 1885, 310 s.

14. O. Trybutska, Materialy osobovoho fondu Pavla Riabkova (do 165-richchia vid dnia narodzhennia vidomoho vchenoho-etnohrafa i hromadskoho diiacha) [Materials of Pavel Ryabkovs Personal Fund (on 165th Anniversary of the Birth of Famous Ethnographer and Public Figure)], in: «Istoriia Ukrainy: nauk.-dopom. bibliohr. pokazhch. za 2013 r.», Kyiv, 2015, s.137-142.

15. Trudы эtnohrafychesko-statystycheskoi эkspedytsyy v Zapadno-Russkyi krai, snariazhennoi Ymperatorskym Russkym Heohrafycheskym obshchestvom. Yuho-Zapadnoe otdelenye. (Materyalы y yssledovanyia, sobrannыe deistvytelnыm chlenom P.P.Chubynskym) [Proceedings of the Ethnographic-Statistical Expedition to the Western Russian Territory, Equipped with the Imperial Russian Geographical Society. Southwest Branch. (Materials and Studies Collected by Full Member P.P. Chubynskyi)]: V 7 t., 1872-1878.

16. Ukrainski narodni pisni v zapysakh Sofii Tobilevych [Ukrainian Folk Songs in Records of Sofia Tobilevych], Kyiv, Nauk. dumka, 1982, 121 s.

17. H. Khalymonenko, Tiurkizmy u profesiino-vyrobnychii leksytsi ukrainskoi movy [Turcisms in the Professional Production Vocabulary of the Ukrainian Language], Kyiv, 1995, 56 s.

18. H. Khalymonenko, Pokhodzhennia slova chumak [Origins of the «Chumak»], in: «Ukrainska mova», Vyp.4, 2010, s.85-88.

Chumaky y pisnia [Chumaks and Songs], URL: https://ua.raskazka.net/tag/legendi/page/33/

19. T. Shevchenko, Kobzar [Kobzar], Kyiv, 1987, 639 s.

20. V. Shcherbatiuk, Chumatstvo: torhovo-viznytskyi promysel ukraintsiv [Chumak Business: the trade and business thought of Ukrainians], in: «Den». 1999. 16 lyp.

21. D. Yavornytskyi, Istoriia zaporozkykh kozakiv: U 3 t.. [History of Zaporizhzhia Cossacks: In 3 vol.], t. 1, Lviv, Svit, 1990, $583 \mathrm{~s}$.

22. V. Yaremenko, Taras Shevchenko pro chumatstvo, yoho zvychai ta pisni [Taras Shevchenko on Chumak Business, Its Customs and Songs], in: Narodna tvorchist ta etnohrafiia, 2005, №2 (295) berezen-kviten, s.21-31. 